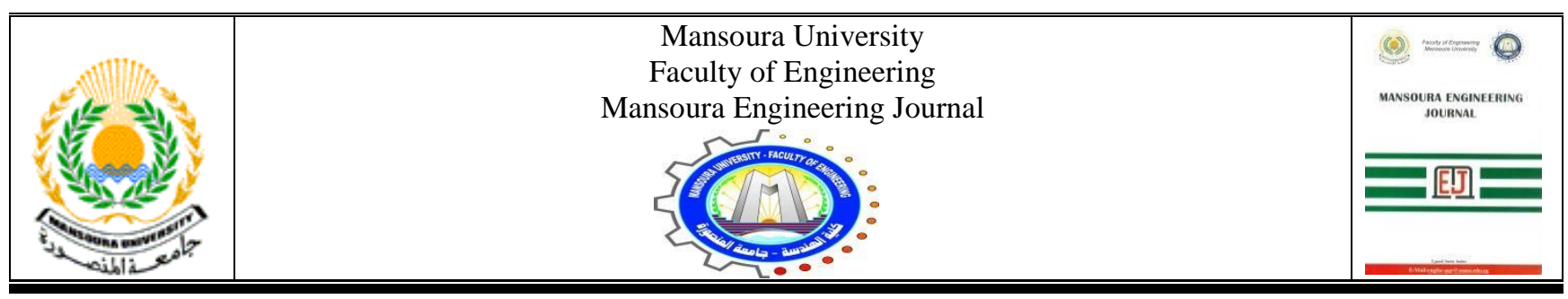

\title{
The Eco- Efficiency of Using Smart Masonry in the Rehabilitation Projects of the Heritage buildings
}

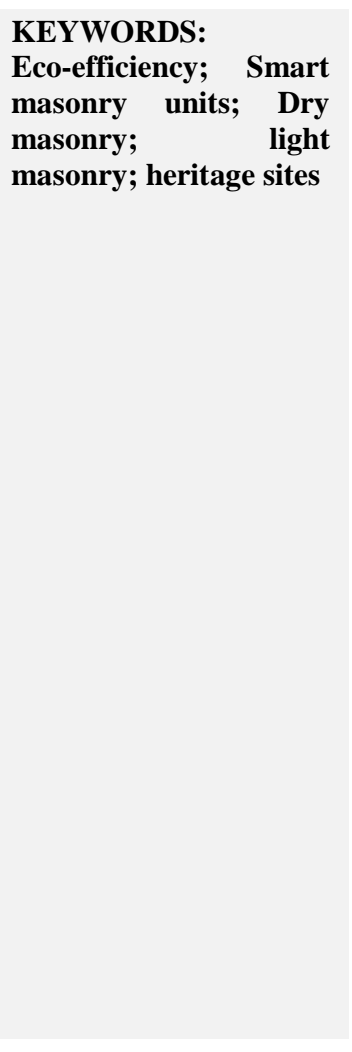

\author{
Elsayed Gehan, Hassan Randa
}

\begin{abstract}
Masonry units are considered to be traditional and environmental materials used in constructing valuable buildings in historic and Heritage sites all over the world. And they are well known for either construction or claddings up-till now. But they sound for various problems while using them in traditional ways as; the massive weight, the limitations of constructing large spans, the low durability while absorbing water or facing more stresses. Moreover, they are costly while maintaining them.

Nowadays the call for sustainable development forced technology to convert the massive material to a smart one which could deal in the site with efficiency as economically or environmentally as called eco- efficient aspects. So the liability issue is that; there is no researches (especially in Egypt in the field of the conservation of the heritage buildings) refer to the usage of the smart masonry in the heritage buildings or the advantages that could be gained by that usage.

The research aim to get important role of smart technology to search for the aspects of efficiency that could be presented in the global era to get solutions to revive the usage of masonry units in the heritage buildings in new integrated constructions or in the additions of the heritage buildings themselves, all within the scope of the sustainable development.

There are two hypotheses in the paper as follows; the first considering that the global technology afforded the construction process by smart materials and systems that can represent many kinds of efficiency suiting the sustainable development.

The second hypothesis: is that the smart masonry have great efficiency while using them in the rehabilitation projects of the heritage site.

The methodology used in this paper to fulfill the hypothesis and reach the main aims is a deductive method begins with a theory(Displaying the new technical masonry and their advantages as means of reaching eco efficiency), and developing hypotheses from that theory(by Assessing the validity of the hypothesis concerning the needed efficiencies of the used construction in the heritage sites, by means of questionnaire directed to the persons concerned the heritage sites development), and then collecting and analyzing data to test those hypotheses(by measuring the efficiency of using the new technical masonry in the additions of the constructions in the heritage buildings, by means of questionnaire directed to the persons concerned the heritage sites development, , civil engineers and industrialists).
\end{abstract}

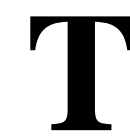

\section{INTRODUCTION}

He terms masonry refers to the block building stone

Received: (9 July, 2020) - Revised: (29 October, 2020) - Accepted: (3 November, 2020)

Corresponding Author: Gehan Elsayed, Associate Prof.: Modern University for Technology and Information (Gehanelsayed2@yahoo.com). used as normal materials of workmanship in the construction systems or claddings for exterior or interior screens, for example, marble, rock, travertine, limestone, cast stone, solid square, glass piece, and adobe. Mainly most the historical and

H. Randa Associate prof.: The Higher institute of Engineering, El Sharouk, Egypt(r.hassan@sha.edu.eg). 
heritage buildings all over the world were constructed from masonry units. But by time these masonry shows many problems affecting their appearance and durability, as while facing the natural environmental factors like; wind, ground water, humidity, and soil salts the stones durability demolish and its lateral appearance is badly affected. (saint john, 2010), (bionda, d. 2006) on the other hand, there are other factors can affect the durability as; the uncalculated loads (dead and life loads) could be added to the existing buildings while the reuse of these buildings or while adding more floors over them. Also, the transportation vehicles when penetrates the streets of the heritage sites or the historical one affects the masonry's durability. But while referring to the conservation rules of the heritage sites where these buildings found there are many constraints concerning the significance of the past "beginning from the leading role1 in developing and promoting heritage conservation principles that set out some common principles which guides the conservation work and controls the relocation, the removing oradding any masonry either in the heritage buildings and realms or the new buildings added in the rehabilitation projects in such sites" (wellington, and james semple kerr, december 1996), (sydney water, 2009), ( heritage branch department of planning, 2009)

So, the usage of any material as an addition in such spaces needs a carful deal and a respectful reason.

At the same time it is to be proven that there are new aspects to improve the construction system in the heritage sites within the smart technology mainly the smart masonry to prove efficiency as follows: Second; the efficiencies of the used construction in the heritage sites are to be as follows: $*$ The Safety of the heritage site

* The maintenance of the construction system

* The durability and the life cycle of the materials used

* The enhancement of the technology in reducing resources used in the construction

* The chosen construction systems of the heritage sites must have High quality public realm.

so, the paper will be divided into four parts as follows:

1 st the new technical aspects used to reach eco efficiency in masonry units.

2nd the efficiency needed while constructing new buildings or additions in the heritage sites.

3rd the efficient cues and the new masonry could be used in rehabilitation projects in the heritage sites.

4 th the conclusion.

\section{TYPES OF DETERIORATIONS OF THE HERITAGE BUILDING}

The most factors causing deteriorations to the elements forming the buildings varies between humidity, the rising ground water table and the over loaded sewage systems and the poor techniques used in the restoration process that had its impact on the restored parts, but the deteriorations can be classified according to their seriousness as, The Inconsequential damage, the Repairable damage and the overall repair or replacement (JERE L1995)

\subsection{Inconsequential damage;}

Problems of this type are of no immediate structural concern, but they do need attention for the structure to maintain its durability, examples of such damage are:

a. Decomposition of lime mortar between stone courses, and between adjacent stone blocks in walls. This is probably due to loss of adhesion of the mortar to the adjoining stone over time, combined with some slight relative motion.

b. Partial wear of blocks made of friable or weak sandstone, mostly due to weathering.

c. Desiccation of new replacement stone blocks because of their poor quality and high porosity.

d. Deterioration of stone and masonry blocks because of probable chemical aggression of gypsum plastering or air pollution.

e. Old sporadic vertical fissures in thick stone walls.

f. Slight old separation at intersections of walls.

Example; the deterioration of the northern wall of al- Azhar mosque due to the humidity and the wind factors in 1915as show in fig (1)

Another example; the limestone blocks that rapidly deteriorated but marble blocks remain stable at al Azhar mosque in Cairo, Egypt in 1992 (JERE L1995)

Also, the disintegration of limestone caused by salt deposits from ground water in al- Ghuri in Cairo, Egypt 1992

and the stone and masonry failure caused by the gypsum plastering used for restoring the wall of Qawsun gate fig (2).

\subsection{Repairable damage;}

In this category damage or problems that need prompt action to avoid potential failure under any future overload or soil subsidence. Examples include;

a. Disintegration of the lime mortar between stone blocks of arches and domes.

b. Through cracks in stone blocks of lintels

c. Continuous vertical separation between stone blocks.

d. Active settlement cracks at wall corner.

e. Local failures in slender elements such as minaret marble columns.

f. Disintegration of stones at wall intersections.

For example; the local failure in a marble column in Sarghatmash mosque fig (3). In Cairo, Egypt after the earthquake 1992

\subsection{Overall repair or replacement;}

In this category structures or parts of structures have already collapsed, or where overall failure is imminent, such as;

a. Severe thrust of domes or arches on abutments or walls.

b. Excessive settlement that has distorted the structure.

c. Tilting and/or displacement of wall corners due to excessive settlement.

d. Disappearance of wooden floors or wall parts in areas where collapse has already taken place.

Examples of such deterioration; the collapse of the temper in house of Ali katkuda after the earthquake 1992.fig (4) (JERE L1995) 


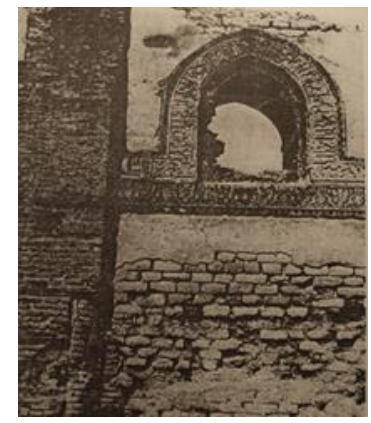

Fig (1) the deterioration of the northern wall of al- Azhar mosque due to the humidity and the wind factors in 1915 (JERE L1995)

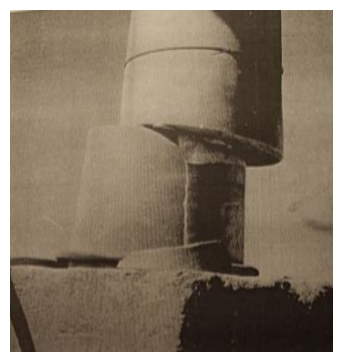

Fig (3) local failure in a marble column in Sarghatmash mosque. In Cairo, Egypt after the earthquake 1992 (JERE L1995)

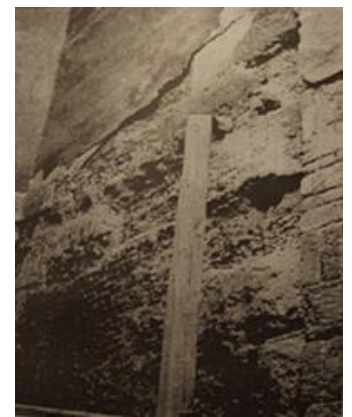

Fig (2) stone and masonry failure caused by the gypsum plastering used for restoring the wall of Qawsun gate (JERE L1995)

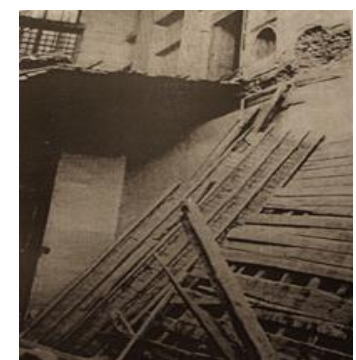

Fig (4) The collapse of the temper in house of Ali katkuda after the earthquake 1992 (JERE L1995)

\section{TRADITIONAL WAYS OF REHABILITATION OF THE HERITAGE BUILDINGS}

In contrast to effectiveness, Efficiency refers to the cost as it means "doing the thing right" not doing the right thing but this act opposes the constrains of the conservation of the heritage items as these items have to be treated in a sensitive manner as Internationally, the leading role in developing and promoting heritage conservation principles set out some common principles that guide conservation work, As the key principle of conservation work is the importance of understanding the significance of a place before making any decisions about its future. Otherwise the heritage significance can be demolished. (Greg B., Jan H.1996). So Statutory heritage listing not only controls the demolition of listed heritage items; it also limits the degree to which changes can be made to them. Also, Legislation requires owners to apply to a consent authority (the local council or the Heritage Council) before making substantial alterations. And there are many exemptions to this requirement for relatively minor works or those that will have minimal effect on the heritage significance of the place. as the aim of the legislation is to achieve a sensible balance between retaining the heritage significance of special places and enabling them to continue to be of use to the owners and the community.

And there are constrains for the change concerning the relocation, the removing, or adding of the items, as follows;

a. Relocation, however, can be a legitimate part of the conservation process where assessment shows that:

(i) The site is not of associated value as an exceptional circumstance.

(ii) Relocation is the only means of saving the structure.

(iii) Relocation provides continuity of cultural heritage value. A new site should provide a setting compatible with cultural heritage value.

b. The obscured items (the hidden items); the material of a particular period may be obscured or removed if assessment shows that this would not diminish the cultural heritage value of the place. In these circumstances such material should be documented before it is obscured or removed.

c. The addition: The only change accepted concerned the installation of electricity, modern plumbing and improved roofing, which were justified on the grounds that they help to protect the historical remains and insure their future use.

So, the efficiency is always accompanied by the significance of the heritage items. So, it must be achieved within effectiveness; doing the right thing with least money or in a sustainable manner.

The most important goal is to obtain an end result that approaches the original stone, brick or concrete as identical as possible (color, texture, elasticity, porosity, dilatation and shrinkage, ...) and to limit possible future side effects (chemical or mechanical). Selection of which type to use, will depend on:

- Compatibility of both materials (the existing stone and the repair-mortar) in all regards;

- 'treatability' of the work (geometrical or formal complex) and the workability of the mortar (= hardening period / level of plasticity,) Work and climate conditions (inside, outside, warm, humidity,) (Greg B., Jan H.1996)

\section{THE NEW TEChNICAL ASPECTS USED TO REACH ECO EFFICIENCY IN MASONRY UNITS}

These aspects varied from smart masonry units daring for efficiency, curing applications done while manufacturing the masonry units or in the construction process itself and sensors used to observe the deterioration of the stones to alarm for maintenance.

\subsection{Smart Masonry Units Involved in The Structure System}

\subsubsection{A Mortar Less Pre- Stressed Masonry (Tech-Dry Masonry)}

The usage of dry masonry began from the past as a dry-stack construction shown in The Pyramids of Giza in Egypt as the limestone ground smooth and fit tight without mortar. And this structure relies on gravity and friction to maintain its stability. A relatively recent adaptation of mortar less masonry has been applied to segmental retaining walls using either gravity or mechanically stabilized earth techniques. This system has been appeared and developed since the late of 1982 in various countries and it has presently systematized in England, New Zealand, Switzerland, Australia, the United States, and others. It uses unique solid stonework units, post-tensioning ligaments, post-introduced ligament grapples, and surface holding. Instead of these units gives flexural quality to the dividers (walls) and a basic attach is utilized to oppose high-wind powers. Surface holding in mix with shear protection opposes water entrance 
and goes about as a complete for the workmanship. Utilizing over the top ligaments, post-tensioning limits the measure of grouting required, leaving the centers of the solid workmanship units accessible for protection. In 1996 Victoria University searched to develop such dry masonry by using silicone Nanotechnology as treating and protecting against rising damp and salt attacks.

The post-tensioning ligaments were intended to initiate pressure in the dividers (walls) to conquer the strain made by out-of-plane flexural loads. The ligaments were composed as along the side controlled and un-reinforced. The minute quality was resolved in light of the hub pressure from the pre-push stack, the incomplete weight of the divider units, and the extra dead load from the rooftop structure where pertinent. So, the outcome is a superior house developed in a short time allotment that is a model for creative plan, cost investment funds, and profitability. (NCMA, 2004).

Applications have primarily been for residential construction, but commercial construction is also possible. And there are several examples of dry-stack systems as shown in table 1

TABLE 1

TYPES OF DRY-STACK SYSTEMS

\begin{tabular}{|c|c|c|}
\hline $\begin{array}{l}\text { The } \\
\text { type }\end{array}$ & Feature/properties & Image \\
\hline 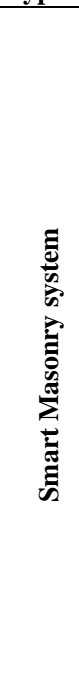 & $\begin{array}{l}\text { It is spread in Australia, it made out of } \\
\text { stretchers and corner units. It is utilized } \\
\text { with grouted development to Provide } \\
\text { basic limit. Notwithstanding its quality } \\
\text { attributes, Smart Masonry } \\
\text { strengthened, and center filled dividers } \\
\text { display the accompanying alluring } \\
\text { properties: } \\
\text { - Longer traverses can be accomplished } \\
\text { than with traditional mortared } \\
\text { stonework because of the higher } \\
\text { trademark compressive quality } \\
\text { - Ductile conduct amid development - } \\
\text { the Smart Masonry divider, before } \\
\text { center filling, acts in a very bendable } \\
\text { way under sidelong load } \\
\text { - a } 140 \mathrm{~mm} \text { fortified and center filled } \\
\text { divider has sound protection } \\
\text { - a } 140 \mathrm{~mm} \text { fortified and center filled } \\
\text { divider has a Fire Resistance Level of } \\
240 / 240 / 180 \text {. Fig. 1. (NCMA, 2004). }\end{array}$ & Fig. 1. (NCMA, 2004). \\
\hline 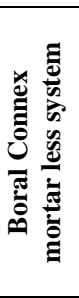 & $\begin{array}{l}\text { This system depends on traditional } \\
\text { fortification as Corner and half units } \\
\text { are accessible in Australia. Fig. } 2 . \\
\text { (NCMA, 2004). }\end{array}$ & Fig. 2. (NCMA, 2004). \\
\hline 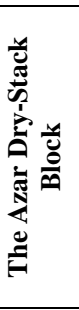 & $\begin{array}{l}\text { Is another minor departure from an } \\
\text { interlocking framework with traditional } \\
\text { fortification, spread in Canada. This } \\
\text { framework is affirmed for structures of } \\
\text { three stories or less. It is available in } \\
\text { Canada Fig. 3. (NCMA, 2004). }\end{array}$ & 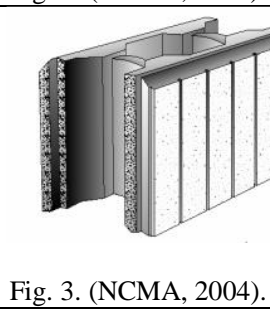 \\
\hline
\end{tabular}

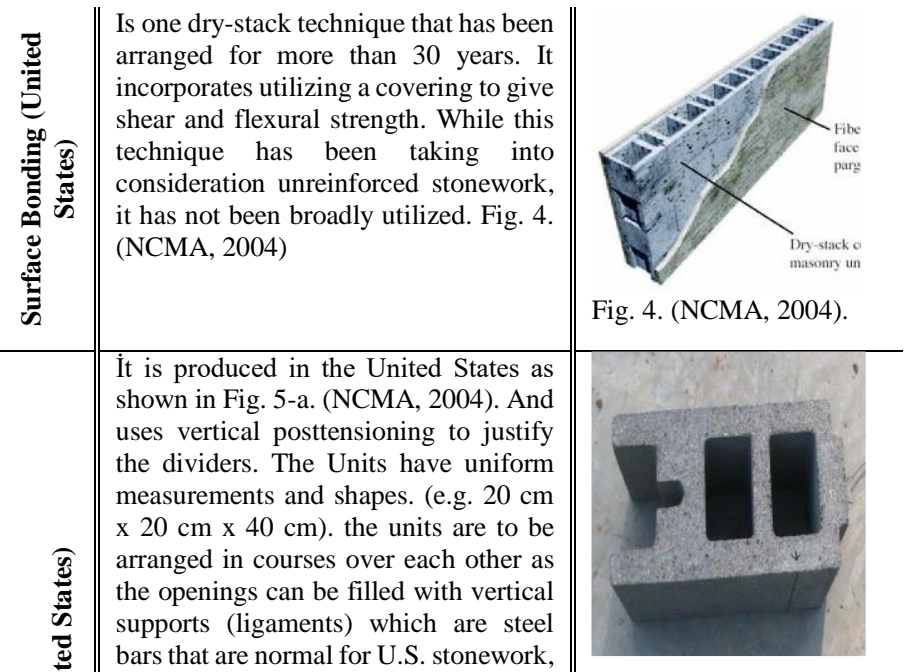

Fig. 5-a. Flex lock masonry Unit. (NCMA, 2004).

\section{leveling of the divider.}

Customary strengthening and grout are utilized for level lintels over openings and might be utilized vertically at supports as conditions warrant.

İt is used in Nesmith Kendra building in India as shown in Fig. 5-b.and these units showes efficiency while manufacturing themm as reducing the used energy (embodid energy) also they sustain the resources (natural materials).

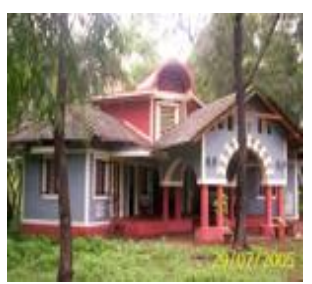

Fig. 5-b. Nirmithi Kendra Building in Inia Http://dknk.org/aboutus.php

\subsubsection{Transparent Masonry Grout Clean}

It is another and inconceivably enhanced framework used to shape get out spreads. It replaces the old-fashioned strategy for affixing get out spreads to the brick work divider. The smart masonry clean-out framework utilizes an unmistakable straightforward window that permits the work obviously screens grout stream amid a grout pour, as any blockage in the cells can be distinguished and rectified before proceeding with the grout pour. with plywood covers, voids in a brick work divider are just recognized after the expulsion of the plywood covers and are regularly at that point concealed by pressing the cell with mortar and leaving the cells over the get out square still drained of grout. this new framework spares time/cash, kills expensive victories that require etching and pounding (exorbitant punch out), makes no harm the substance of the square, can be introduced ahead of time of the review taking into account availability to pour grout promptly after investigation, can be introduced and evacuated in seconds and it has erosion safe. the straightforward window joins to the brick work divider by means of a one of a kind and licensed t-bolt and nut. both the straightforward window and nut are re-usable. with this new framework the workmanship contractual worker can convey a quality item appropriately grouted/fortified stonework dividers that the designer can approve and eventually to the proprietor who all things considered, has paid for a quality item. fig. 6 . 


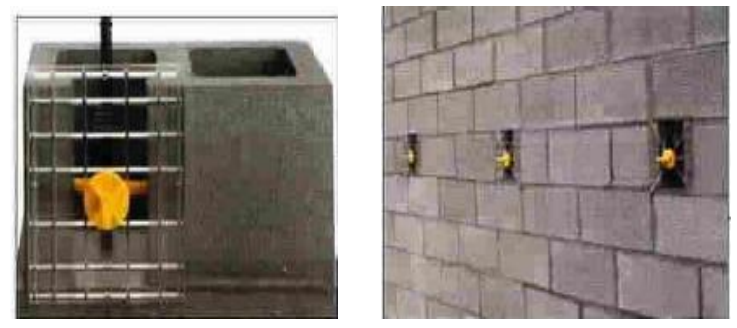

Fig. 6. the Transparent masonry grout clean

\subsubsection{Legos Brick (Dry System)}

It is a modular connecting bricks which began with plastic block that have tried the basic furthest reaches of Lego with full-scale develops, including a few monstrous towers that, paralleling high rise development, get higher consistently as block manufacturers race for the record (a hypothetically perpetual interest). And after that there was the 3.3 million block full-estimate Lego house worked in 2009 by "Top Gear" moderator James May and a multitude of volunteers for the network show "James May's Toy Stories." While great, these full-measure creations aren't generally useful as something besides curiosity showstoppers and blog grub. In any case, another organization is proposing to change that with a really design snap-together block that may really be valuable (while as yet being great blog grub, obviously). (Ngowi, J.V.; Uzoegbo, H.C (2005)

The organization Kite Bricks is at present building up a secluded development framework that is so much like Lego, as shown in Fig. 7.The invention includes a method for constructing a multi-story structure without internal columns, including the following: selecting a site for construction of a structure; preparing a floor from a plurality of prefabricated blocks and finished floor pieces, wherein the blocks have complementary joining features on their sides as well as joining features for securely holding the finished floor pieces; placing a first majority of building hinders in a straight line over the floor, wherein the line characterizes a mass of the structure and wherein the squares have top sides that incorporates first joining highlights, base sides including a corresponding second joining highlights, connectors for side-to-side connections between blocks, and inner spaces including removable faces, the spaces adapted to accept infrastructure elements; setting a moment majority of building hinders on the primary majority of building pieces, wherein the second majority of building squares are secured to the main majority of building obstructs through joining highlights and double-sided tape; adding additional building blocks until a predetermined height of the wall has been reached; placing a ceiling over the blocks, wherein the ceiling is prepared from blocks with joining elements adapted to join with elements from the highest blocks of the wall; laying flooring pieces over the ceiling to form a floor of a second story; building additional walls of the structure above the floor; repeating steps of erecting a ceiling and building additional walls above the ceiling; and, completing construction of the structure, wherein the blocks are used in the construction of all internal and external walls of the structure, as well as floors, ceilings and roof of the structure of a predetermined number of stories Fig. 7. This system has many advantages as;

- does not require mortar or internal columns

- doesn't require additional internal or external finishing there is no extra need to paint, hang backdrop or generally treat the external and internal dividers of the last structure

- It represents an insulation and energy saving materials.

- The block includes a removable face for allowing access to space for infrastructural elements like wires and pipes. In another aspect the face is transiently removed by the aid of a vacuum.

- The building blocks include elements to accept prefabricated windows or doors.

- The building blocks include blocks that may be used in building of a roof.

- The elements for self-joining allow for contact between blocks, wherein the contact does not allow for passage of wind or rain.

- The blocks may be made of any relevant materials or combinations of materials. Concrete, carbon fibers, sand, chalk, metal, glass, marble, carbon composites, stone, and plastics are all non-limiting examples of materials that may be used either for constructing blocks or for combination in the construction of blocks used as per the instant invention.

- The honeycomb elements allow for very tight block to block attachment.

- L-shaped blocks or blocks built at 90 degrees may be used to affect corner construction.

- There are the ease and speed with which construction is performed.

- Blocks are produced from polymeric material from a threedimensional printer to final dimensions of 50/60 centimeters in length, 25/30 centimeters height, and $5 / 10 / 20$ centimeters in width. The blocks are hollow and have multiple holes for the passage of wires and pipes. The blocks additionally include insulation made from fiberglass.

- The blocks may be painted and or treated to create unique inner and outer finishes prior to use of blocks in construction of a plurality of walls in a structure. The finishes may be bonded, glued, or otherwise associated with the blocks.

- Special glue may be employed to hold blocks from a ceiling structure together-blocks being connected through joining elements in the side of the blocks. 

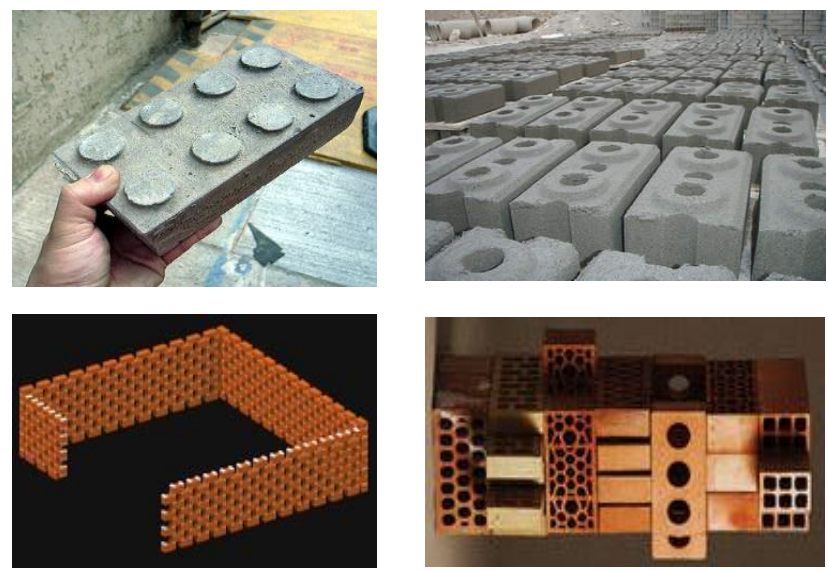

Fig. 7. The Legos blocks

\subsubsection{Light Masonry}

In old decades architecture produced heavy stone masonry as it is often heavy, massive, and incorporates less natural light than alternative methods, but recently Smart Masonry applied by ZA architects (Dmytro Zhuikov and Arina Agieieva) are proposing to change masonry buildings and open opportunities for digital fabrication techniques in stone and other previously antiquated materials. Designers derived the foundations and construction methods of their new structural system in the Project DIA Hochschule Anhalt location: Berlin, Germany, shown in Fig. 8. this project was undertaken as the master theses' of ZA architects. The Smart Masonry is a structural design and a construction method, based on traditional masonry techniques. It deploys the digital optimization to minimize dead-weight of the skeleton and the robotic construction technique to assemble complex geometry.

Every 'cell' that constitutes a structure is produced using an elastic determined froth substance. a 4-hub hot-wire cuts the frame utilizing a PC display as guide, empowering complex shapes in almost no time. The piece is then soaked with a blend of port-arrive concrete and left to solidify; distinctive froth porosities compare to different last exhibitions. Once cured, the workmanship is done and prepared to be taken to the site. It is accepted by the fashioners that such a technique will incredibly build development speed, while diminishing vitality and material use .

The proposed technique is connected to the reason and place of the building-Makers Center in Berlin. The hardware, which utilized for the development of the building, will be saved as it's a center and will drive its fundamental capacity. The basic idea speaks to one consistent work, rather than dividers, segments, pillars, and so forth. It is composed as a negligible surface, whose pressure design is streamlined and appeared as a heap bearing example. The development strategy blends favorable circumstances of $3 \mathrm{~d}$ printing and extensive pre-assembled components. The robotic construction station with robotic arm manipulators allows the build of a complex geometry floor-byfloor. It is compact and labor-effective comparing to traditional methods, and fast comparing to $3 \mathrm{~d}$ printing. As shown in Fig. 8.

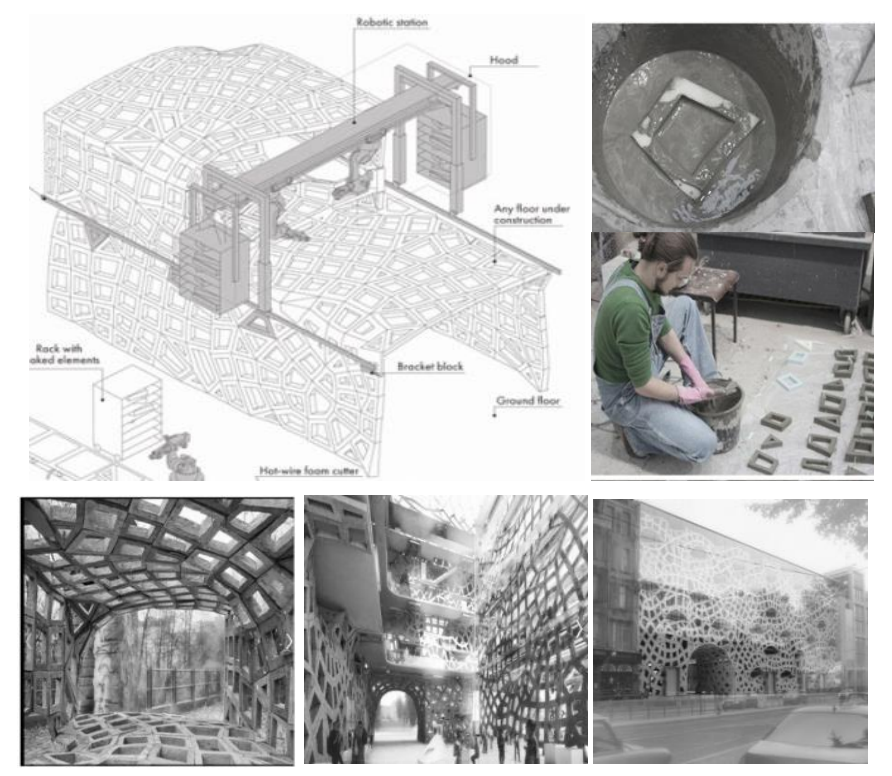

Fig. 8. shows the interior and exterior of a building formed from Smart Masonry, Berlin, Germany by Dmytro Zhuikov and Arina Agieieva, 2015

http://zaarchitects.com/en/public/125-smart-masonry.html

\section{4 r.Eco Cladding materials}

Nowadays Temporary technology offered various economic claddings as follows:

\section{I, 1. Dry - Hang fixing stone (interlocks)}

These cladding stones are prefabricated stones with admixtures to enhance their properties, each stone or panel interlocks with each other with the tongue joining channels into factory pre-grooved rebates. This makes them significantly faster than traditional mortar and dry hang fixing which lowers costs. No more wet weather holdups or expensive specialist trades required, at the point when introduced as per the guidelines this framework gives an entire waterproof boundary securing the vital basic texture of the building.as shown in Fig. 9.

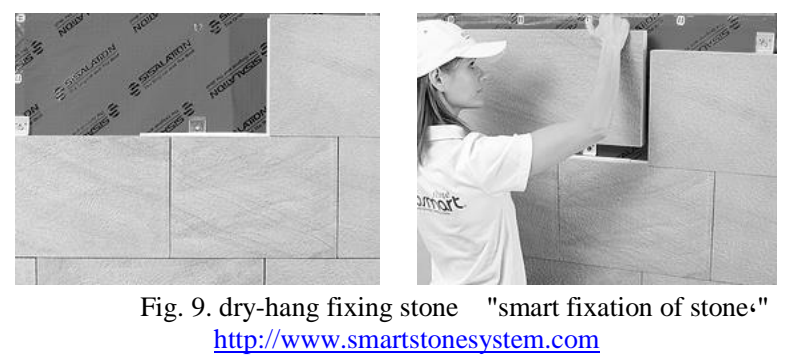

\subsubsection{Glued}

They are eco smart Stones stone used as forms of cladding stone can be arranged on meshes in factories to be glued on the envelopes. The range comprises of various numbers of Series of formats with single blocks at special dimensions, as shown in Fig. 10 with interlocking stone sections in easy handling large $1200 \mathrm{~mm} \times 300 \mathrm{~mm}$ height panels. Panels simply lock together. 


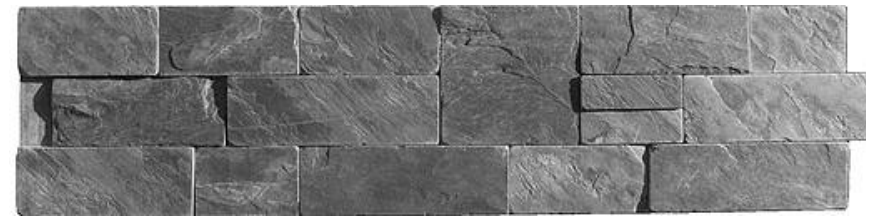

Fig. 10. a panel of The Eco Smart Stone " the eco stones", http://static.wixstatic.com/media

\subsection{Dry buildings protection systems}

These systems are of different types as some of them can be fitted in the process of fabricating the masonry units. As by adding them some new properties can be achieved by the masonry units or the contents properties can be enhanced, as; the Pre-sealing nanotechnology, Salt Retarder and Non-toxic water-based formulation. On the other hand, there are external protectors or enhancers as creams, sprays and polishers that can protect the masonry units externally and penetrate inside it to enhance its properties, as shown in table 2. (Wight, G.D, Ingham, J. M., Wilton, A.; 2007)

TABLE 2

The Dry Buildings Protection System and Their Properties The

\begin{tabular}{|c|c|c|}
\hline \multicolumn{2}{|c|}{$\begin{array}{l}\text { The } \\
\text { protection system }\end{array}$} & Feature/ properties \\
\hline \multirow{3}{*}{ 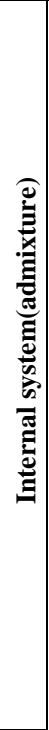 } & 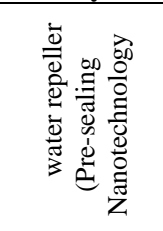 & $\begin{array}{l}\text { Nano silicon is added while manufacturing } \\
\text { pressed concrete products (Tech-Dry Masonry). } \\
\text { These admixtures significantly reduce water } \\
\text { absorption in the concrete, and hence reduce the } \\
\text { presence of unsightly long-term efflorescence and } \\
\text { concrete mould discoloration. and the surface } \\
\text { does not need any further treating. }\end{array}$ \\
\hline & 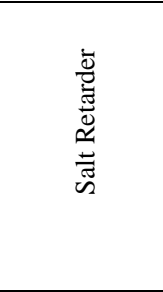 & $\begin{array}{l}\text { It is a water repellent admixture, providing } \\
\text { rising damp treatment that inhibits the penetration } \\
\text { of water and salts when added to cement/sand } \\
\text { renders. It is an admixture which delivers three } \\
\text { properties to the cement/sand render which } \\
\text { plasticises the render mix and provides water and } \\
\text { salt resistance.It may also be used on a new wall } \\
\text { to provide rising damp treatment and prevention } \\
\text { on cement/sand render. }\end{array}$ \\
\hline & 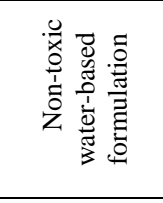 & $\begin{array}{l}\text { It Enhances workability of concrete/sand } \\
\text { renders. Builds grip of concrete/sand renders. } \\
\text { Lessens water entrance, blossoming and water- } \\
\text { borne recoloring. Does not fundamentally change } \\
\text { vapor penetrability of concrete/sand renders. } \\
\text { Simple to utilize and financially savvy. }\end{array}$ \\
\hline 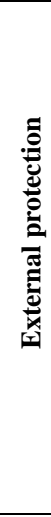 & 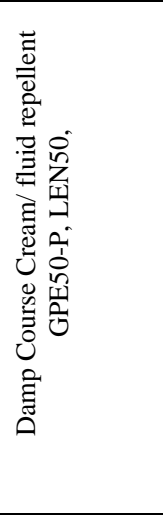 & $\begin{array}{l}\text { DPC Fluid is an environmentally friendly } \\
\text { silane/ siloxane -based impregnate specifically } \\
\text { formulated to permeate into wet walls as a damp- } \\
\text { proof course in masonry walls. } \\
\text { It is another silane/siloxane emulsion think } \\
\text { with an improved surface beading impact. It is } \\
\text { intended to supplant dissolvable based } \\
\text { silane/siloxane to create a water-based silicone } \\
\text { sealer with a solid water repellent impact. } \\
\text { Tech-Dry Protectasilane 100 can be } \\
\text { connected utilizing brush, roller or shower. } 100 \% \\
\text { dynamic with no hydrocarbon dissolvable utilized } \\
\text { Ability to profoundly enter into thick cement } \\
\text { Permanently bonds to the solid with no peel or } \\
\text { rankle Forms UV, soluble base steady and sturdy } \\
\text { siloxane structure inside solid grid Reduces water }\end{array}$ \\
\hline 矛 & & $\begin{array}{l}\text { infiltration, blossoming and the entrance of } \\
\text { hurtful salts, for example, chloride particles Does } \\
\text { not fundamentally change the surface appearance } \\
\text { and vapor penetrability }\end{array}$ \\
\hline
\end{tabular}

It is an environmentally friendly water-based oil and water repellent utilized as a stain safe sealer for treating stonework substrates. The treatment does not change the surface appearance or vapor penetrability of the substrate. Additionally, it gives phenomenal security against the dominant part of stains including nourishment. It contains no natural dissolvable, so it is reasonable for all workmanship materials including regular stone, solid piece, pavers/garages, block, earthenware, tiles and grout. Due to be a water-based item, it has constrained infiltration capacity in thick substrates so the item might be most appropriate for treating porous stonework substrate.

Emulsion PCW50E produces an aesthetically pleasing finish by highlighting contrasting colors in the substrate.

The treatment won't essentially change the appearance and vapor porousness of the substrate surface. Notwithstanding, a slight obscuring of the surface may happen for a few substrates.

It is an exceptionally planned infiltrating solid sealer containing dynamic lithium silicates. It is likewise reasonable for clean verification or water-confirmation fixing of

rete sealer enters into the solid surface and hinders the pores or vessels by arrangement of calcium silicate hsolid workmanship if connected properly.

This concydrate. This calcium silicate hydrate ties inside the solid framework and solidifies the solid surface bringing about hard, thick, clean free and movement safe surface wrap up. Smooth or sparkle completions can be effortlessly accomplished by surface cleaning. This Tech-Dry solid sealer quickens the solid cleaning process, consequently sparing time and expenses. Not at all like conventional sodium silicates, this sealer impossible leave deposits, for example, has white flower salts or other undesirable buildup stained on the treated surface.

This limestone sealer is a non-caustic and user-friendly item, which is intended to enter profoundly into the vessels of limestone surfaces and render the substrate water repellent and fortify the surface. It will not significantly change the appearance. As a deeply penetrating silicone sealer, it can be used as a marble sealer, which leaves the marble with a natural finish, without affecting the marble's natural appearance.

\section{It is a specially formulated cleaner to remove} organic stains, from brick work surfaces, for example, solid pieces, pavers, sandstone items, earth dividers and other stonework substrates

By brushing No More Stains over the recolored territory and abandon it absorb for 5-10 minutes or until the point when stains vanish. Flush the surface with clean water. Because of their porous surfaces, workmanship building materials can be effortlessly recolored by oil, oil, sustenance and earth bringing about perpetual recoloring. It acts on colored masonry and lightcolored concrete and natural stone which can be easily stained by a variety of staining materials. 


\begin{tabular}{l||l} 
It is a penetrating silicone sealer that \\
combines excellent with water and stain to \\
produce an aesthetically pleasing finish by \\
highlighting contrasting colors in the substrate. \\
This can be particularly gratifying on concrete \\
pavers, polished concrete, exposed aggregate, \\
honed concrete, ceramic and natural stone tiles. \\
Fantastic protection from oil and water-based \\
stains Reduce water ingestion and green \\
growth/form development Penetrates and \\
securities to the stonework substrate Durable \\
insurance and wear protection Easy to apply. The \\
product can also be applied using a brush or roller.
\end{tabular}

\subsection{The Usage of Sensors (Oliver Gronz, Et Al, 2016)}

Plenty of different sensors, visual, active or passive tracers exist to capture movements of the stone in their actual place in various ways. And such task for these observers is very important for several geo-morphological and hydrological forms and in addition building applications. This incorporates quick developments like shake falls or different mass developments in high mountain districts, slower developments in fluvial and chilly conditions, and disintegration security measures. However, these sensors were expansive in measure that effect and farthest point their use, yet in the most recent period shrewd sensors are utilized as being little in estimate as; the Smart stone test. It comprises of a metal barrel (breadth 8 $\mathrm{mm}$, length $55 \mathrm{~mm}$ ) with an adaptable reception apparatus and contains a Bosch BMX055 sensor made out of a tri hub accelerometer, magnetometer and gyrator, separately. Extra segments inside the test are memory to store information, dynamic RFID (Radio-recurrence recognizable proof) method to transmit information and two catch cells as power supply. The RFID innovation shown in Fig. 11. is useful for the confinement of tracer stones as the test can at present get radio flags regardless of whether it is in resting mode. (Anderson G.L., Mullins, P.J., 2001).

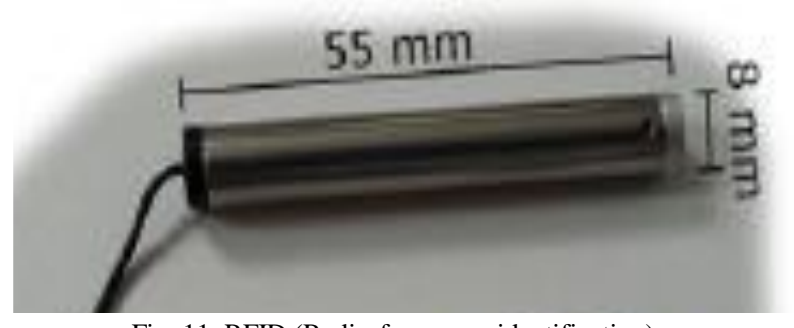

Fig. 11. RFID (Radio-frequency identification) sensor

\section{The EFficiency NeEded While Constructing NeW BUILDINGS OR ADDITIONS IN THE HERITAGE SitES}

The questionnaire has been directed to the persons concerned the heritage sites development, and the majority insisted that the efficiency needed while constructing new buildings or additions in the heritage sites are as follows:

- $\quad$ The Safety of the heritage site.

- The efficiency of the maintenance process

- The enhancement of the technology in reducing resources used in the construction

- The production of the High-quality public realm

Moreover, they insisted that the durability and the life cycle of the materials used are a part of the efficiency of the maintenance process.

\section{The EFFicient Cues ANd The New MASONRY COULd BE USED In REHABILITATION PROJECTS IN THE Heritage Sites.}

The questionnaires have been directed to the persons concerned the heritage sites development, civil engineers and industrialists. And their responds represent an assessment for the efficiency of using the new masonry in the rehabilitation projects in the heritage sites.

\subsection{The Safety of the Heritage Site}

This means maintaining the heritage site from pollution and damages, since the implementation process of the construction in the site till the maintenance process.

The new technologies act with dry applications and refer to the modularization, so they facilitate the transportation to the site and don't need professional labors, at the same time the carbon emissions will be demolished. Moreover, the grout and the infra-structure can be implemented easily within the transparent blocks or from the removable faces in the blocks. At the same time the construction process needs no finishing (exteriorly or interiorly). And the smart dry systems keep the site clean without any attack.

On the other hand the smart masonry displayed by ZA architects are lighter than the traditional one so while using it in making additions on the heritage buildings it wouldn't add more dead loads on the building, so it can keep the structure system safe.

\section{2 The Maintenance Process.}

The new masonry displayed above dare to match with the seventeenth session of the General Conference of UNESCO in Paris in 1972 (the conservation must guarantee that compelling and dynamic measures which are taken for the security, preservation and introduction of the social and characteristic legacy arranged on its region. As each new operation must be done carefully taking into consideration its maintenance). As they fulfill this part of maintenance and play on sustaining the materials. On the other hand, they extend for the useful economic life of the buildings and the length of time it is used for; moreover, they encourage the conservation of nonrenewable resources. 
For example, while talking about fire resistance; it is shown that all the adaptive and smart units and claddings resist fire, also the Nano coatings have smart effect on the new tech masonry as they strengthen them and make them fire resistance.

Tech-Dry Masonry resist moisture, efflorescence and mold - No rising damp - Surface remains clean, pristine and colorfast - Masonry remains dry and can be laid in wet weather Innovative textures and contemporary colors available.

At the same time smart masonry wouldn't need any fixation while exposing to any over stress as it has smart actions and acts as a durable material. On the other hand, the smart stones could be fixed easily as each stone or each stone panel could be removed from the total construction or cladding by a dry method and could be replaced be another one. (Wellington, and James Semple Kerr, December 1996).

Also, the traditional materials can act as smart one while adding sensors reporting their deteriorations, and quickly can be cured by the smart curing additions like; water repelled, Presealing nanotechnology, Salt Retarder....

So, the smart applications directly convert the materials to be smart of no need to maintenance or when it could need maintenance the applications fulfilled in smart way.

\subsection{The Enhancement of the Technology in Reducing Resources Used in the Construction}

Revising the meaning of Sustainable improvement as: "the advancement addresses the issues of the present without trading off the capacity of future ages to address their own issues ". So, it is often associated with the conservation of nonrenewable physical resources.

While referring to the smart materials it is shown that most of them are related to composites and recycling of the natural materials which enhance the concept of sustaining the natural resources.

Also, smart units are standardized and have various size and special units as corners so in the implementation process no units are presented for demolishing moreover, they don't need any finishing. So, the resources are sustained.

\subsection{High Quality Public Realm}

This point of assessment seeks to fulfill two categories as follows; to start with, urban legacy helps fashion national personalities, which empower individuals to characterize their identity and where they are. Furthermore, urban legacy may have accepted monetary significance, as individuals progressively need to reuse their notable territories and structures as assets for exchange and tourism to expand their salary. As urban protection conveys two fundamental advantages with it as character and utility, which allude separately to preservation and improvement.

To fulfill the identity; Tech-Dry Masonry, besides being for protection against the environmental harms, is manufactured as decorative concrete blocks, bricks, pavers, retaining wall units and tiles, which can be made with either close to natural stone appearance, innovative textures or contemporary colors.

While seeking for fulfilling the utility; new technologies of producing materials offer the standardized units which can help in reshaping the envelope of the building to suit the new use, as shown in ZA architects project. And this could be done in a smart way to the heritage style. So there will be harmonies between old and new patterns and elements, rather than broadening the gap between them.

\section{The CONCLUSION}

Nowadays technology has a main issue to reach ecoefficient adaptive materials; as to allow the average new home builder/renovation consumer access to a beautiful zeromaintenance, energy efficiency, efficiency of natural light and lightweight products that is actually affordable. It is also to make installation easy and fast enough for the workers. Furthermore, complex geometries can be accomplished through some of them as; ZA engineers' framework that utilization the mechanical development procedures to guarantee that every component can be reproduced with a similar exactness each time.

And while referring to the heritage sites it seems that new technological masonry units could be used in either the new added buildings or in the additions of the heritage buildings themselves, as they are smart, light and have a call for efficiency.

And the Paradox of the new technology in producing smart materials match the Conservation and the Development of the heritage site, as shown in table (2) as; Urban preservation is tied in with enhancing and redesigning life of individuals in legacy destinations and not simply an issue of reestablishing materials.

TABLE (3)

The Role of Efficiency of the Smart Masonry

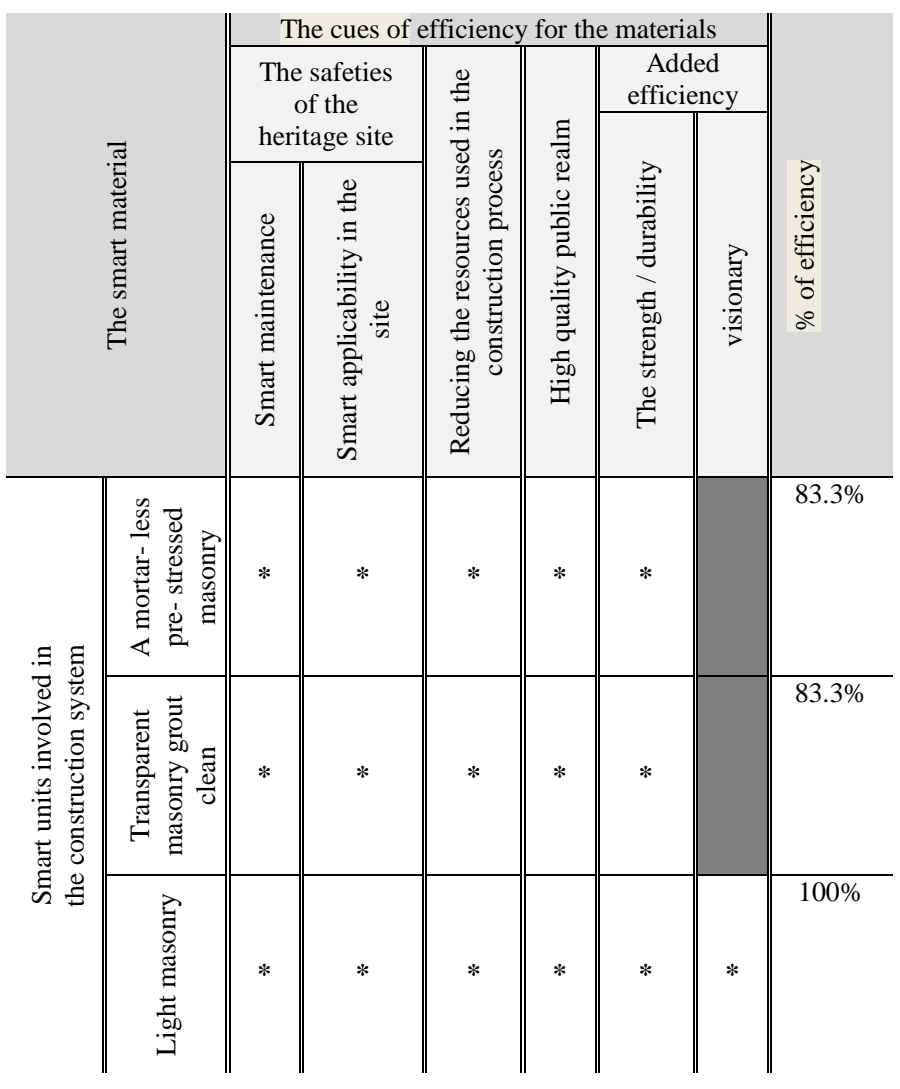




\begin{tabular}{|c|c|c|c|c|c|c|c|}
\hline & $\begin{array}{l}\stackrel{0}{\Xi} \\
\Xi \\
0 \\
0 \\
.0\end{array}$ & $*$ & $*$ & $*$ & $*$ & $*$ & $83.3 \%$ \\
\hline \multirow{2}{*}{ 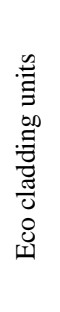 } & 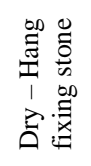 & $*$ & $*$ & $*$ & $*$ & $*$ & $83.3 \%$ \\
\hline & 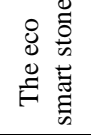 & $*$ & $*$ & $*$ & $*$ & $*$ & $83.3 \%$ \\
\hline 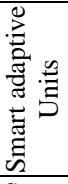 & 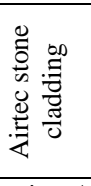 & * & $*$ & $*$ & $*$ & & $67 \%$ \\
\hline \multicolumn{2}{|c|}{$\begin{array}{c}\text { Smart coatings/ } \\
\text { enhancers }\end{array}$} & $*$ & $*$ & $*$ & * & $*$ & $83.3 \%$ \\
\hline
\end{tabular}

Note: * means fulfilled means unfulfilled

\section{REFERENCES}

[1] Anderson G.L., Mullins, P.J., "Smart Masonry - An Innovative Dry Stacked Reinforced Masonry System," Proceedings 6th Australasian Masonry Conference, Adelaide, Australia, July 2001

[2] Bionda, D., 2006, "Modelling Indoor Climate and Salt Behaviour in Historic Buildings: A Case Study. Swiss Federal Institute of Technology Zurich". Zurich, Swiss Federal Institute of Technology Zurich.

[3] Heritage branch Department of Planning, heritage council of new Wales, 2009; "Assessing Significance for Historical Archaeological Sites and 'Relics"

[4] Ngowi, J.V.; Uzoegbo, H.C.; "Empirical Studies of8 878 Flexural Strength for Dry-Stack Interlocking Masonry," Botswana Journal of Technology, Vol. 14, No. 2, (2005), pp. 26-31.

[5] Saint John, 2010, "Saint John Heritage conservation areas: Masonry" http://www.heritagecanada.org/sites/www.heritagecanada.org/files/Saint John_Masonr y.pdf

[6] Sydney Water, 2009;"Veteran Hall Conservation Management Plan, Archaeological Site, Prospect", unpublished report based on a study conducted by Archaeology and Heritage Pty Ltd.

[7] Wellington, and James Semple Kerr, December 1996."The Conservation Plan: A Guide to the Preparation of Conservation Plans for Places of European Cultural Significance, National Trust", Sydney.

[8] Wight, G.D, Ingham, J. M., Wilton, A. "Innovative Seismic Design of Post-tensioned Concrete Masonry House," Invited paper, Canadian Journal of Civil Engineering, In press 2007.

[9] B.M. Feilden, (1985), "Architectural and Urban Conservation", Town Planning 56, 2

[10] CNU (2007). Charter of the New Urbanism. Retrieved August, 2007, from http://www.cnu.org/sites/files/charter_english.pdf

[11] DIX, G. B. (1995), "the Re-use of Buildings in Historic Towns: A Coincidence of Economic and Cultural Activities". Ekistics. 268

[12] Environment, Heritage and Local government, Energy Efficiency in Traditional Buildings, Energy Research Group Ucd, Published by The Stationery Office, Ireland (2010)

[13] G.L. Anderson, D.L. Beal, D. Smart Masonry - An Innovative Dry-Stack Concrete Masonry System Paper presented - 20th Biennial Concrete Institute of Australia conference, Perth

[14] Feilden, B. M. (1985), "Architectural and Urban Conservation, A Review of the State of the Art". TPR, 56, 197-221.

[15] Greg Bowron and Jan Harris, 1994;"Guidelines for Preparing Conservation Plans, New Zealand Historic Places Trust".

[16] "Heritage Information Series A Guide to The Heritage System" Originally published October 1996, Updated March 2005www.heritage.nsw.gov.au

[17] ICOMOS, The Venice Charter- (ICOMOS, Venice, 1994). 12 Andrew King, The Politics of Position, Traditional Dwellings and Settlements Review, 4-2, (1993).
[18] O. Graber, (1993), "Why History; the Meanings and Uses of Tradition, Traditional Dwellings and Settlements" Review 4, 2 - G. B. Dix, "A Sure and Proper Foundation - Conservation and the Future of Urban Design' Report of the Third International Congress on Architectural Conservation and Town Planning (The Heritage Trust, London, 1987.

[19] STEINBERG, F. (1996), "Conservation and Rehabilitation of Urban Heritage in Developing Countries". HABITAT INTL, 20, 463-475.

[20] Steinberg, Florian. (1996), "Conservation \& Rehabilitation of Urban Heritage in Developing Countries"- HABITAT INTL., Vol. 20, No. 3

[21] UNESCO, The General Conference of UNESCO, the seventeenth session - Article 1,5, Paris, October.1972.

[22] United Nations Conference on Environment and Development, Agenda 21, Pre-conference draft report (United Nations, New York, June 1992).

[23] JERE L. BACHARACH, 1995; "the restoration and conservation of Islamic monuments in Egypt", The American University in Cairo press, EgyptINTERNET

[24] Greg B., Jan H. "Guidelines for Preparing Conservation Plans, New Zealand Historic Places Trust", Wellington, and James Semple Kerr, December 1996."The Conservation Plan: A Guide to the Preparation of Conservation Plans for Places of European Cultural Significance, National Trust", Sydney.

[25] https://www.google.com.eg/url

[26] National Concrete Masonry Association (NCMA), 2004. "TEK 15-5A Segmental Retaining Wall Design," NCMA TEK-NOTES.

[27] "Transparent masonry grout clean", E-mail: info@CIF.org • www.CIF.org

[28] "Smart brick, http://www.smithsonianmag.com/arts-culture/no-moreplaying-around-smart-bricks-are-architectural-legos180952215/\#ohSu4AuejhoBgX0w.99

[29] " Smart stone ", http://www.archdaily.com/tag/masonry,

[30] " Smart stone ", http://zaarchitects.com/en/public/125-smartmasonry.html

[31] " smart fixation of stone ", http://www.smartstonesystem.com

[32] " The eco stones", http://static.wixstatic.com/media

[33] " Eco cladding stones ", http://www.r-control.com , http://www.sips.org/

[34] " Eco cladding stones ", http://www.wfm.co.in/cladding-materials

[35] "The eco stones"http://www.wfm.co.in/wpcontent/uploads/2015/11/hospital-ludhiana1.jpg

[36] "The eco stones"http://www.wfm.co.in/wpcontent/uploads/2015/11/punjab-kesari-headquarters-1.jpg

[37] Eco-Friendly Concrete Sealers \& Masonry Coatings Seal-Once.mht

[38] Protective Nano coatings - Nano slic Protective Ceramic Coatings, https://nanoslic.com

[39] Nano-coating provides watertight solution - $\mathrm{CNN}$, www.cnn.com/.../mobile/p2i-liquid-repellent-nano-coating/index.html Oliver Gronz, etal, 2016," Smartstones: A small 9-axis sensor implanted in stones to track their movements, journal homepage:

www.elsevier.com/locate/catena, , Catena p 245-251

\section{Title Arabic:}

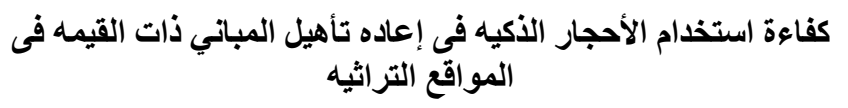

\section{Arabic Abstract:}

يعتبر الحجر من المواد التقليدية والبيئية المستخدمة في بناء المباني القيمة في

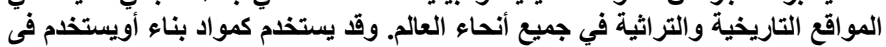

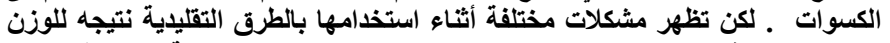

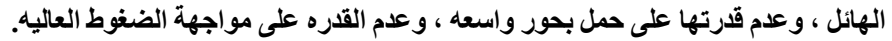

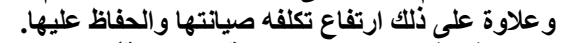

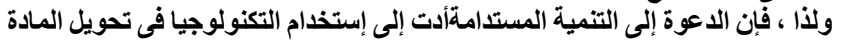

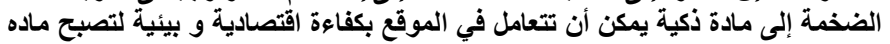

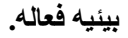
ولهذا فإن المشكله البحثيه تتحصر في كيفيه استخدام التكنولوجيا الذكية في المباني

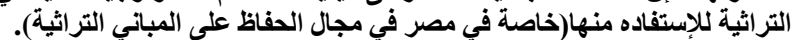

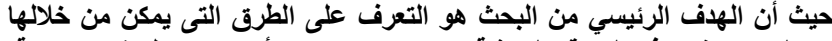

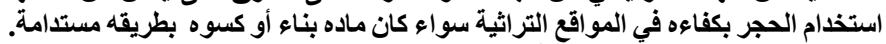

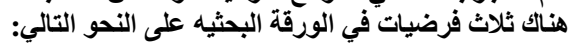

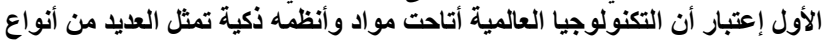
الكفاعة التي تناسب التنمية المستدامة. 


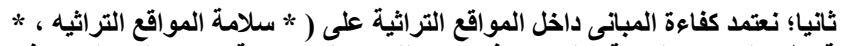

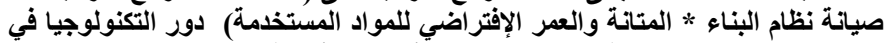

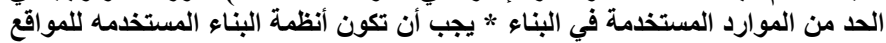
التراثيه ذات جوده عاليه. الفرضية الثالثة: هي أن الحجر الثيه ألثي يتمتع بكفاءة عالية أثناء استخدامه في مشاريع إعادة تأهيل المواقع الترأثيه. هي المنهجيه المستخدمة في هذه الورقة لتيه لتحقيق الفرضية والوصول إلى الأهداف

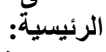
تعريف الحجر الذكي د ومزاياه كوسيلة للوصول إلى الكفاءة البيئية.
ثانيا: قياس كفاءة استخدام الحجركماده بناء أو تكسيه في المواقع التراثية ، عن طريق المباني

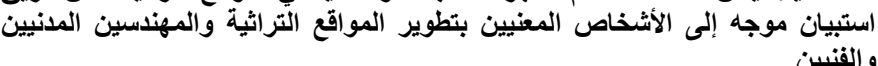

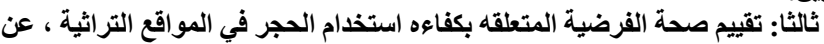
طريق استبيان موجه إلى الأشخاص المعنيين بتطوير المواقع التراثي 